| Volume-1 | Issue-1| Jun-Jul -2019 |

Short Communication

\title{
Gene Expression in Leaves and Epidermis of Arabidopsis under Salt and Drought Stress
}

\author{
Khalifa Suleiman Mohamed* \\ University of Al-Jabal Al Gharbi, Libya \\ *Corresponding Author \\ Khalifa Suleiman Mohamed * \\ Article History \\ Received: 12.07.2019 \\ Accepted: 25.07 .2019 \\ Published: 30.07 .2019
}

\begin{abstract}
Gene expression induced by drought and salt stress also, difference genes in different time are induced with different stresses. Plants of Arabidopsis were divided into groups one under salt stress and others are to drought for 6 h. Most genes are expression in both leaves and epidermis under both treatments. However, DREB2Awas more highly expression in leaves at control and epidermis at $2 \mathrm{~h}$ of drought stress as compared with other treatments.
\end{abstract}

Keywords: Salt, Arabidopsis

\section{INTRODUCTION}

Severe environmental stress can be responsible for up to $65 \%$ of decreases in plant yield, and salt and drought stresses are two of the major factors which cause this [1]. Drought and salt stresses can be connected because drought can cause soil to become salty directly or indirectly through irrigation. Growth rates are lower and biomass accumulates more slowly in roots under salt stress For example, when barley was exposed to $100 \mathrm{mM} \mathrm{NaCl}$ and $0.1 \mathrm{mM} \mathrm{Ca}^{+}$growth and development were reduced, including reduced root hair density and root thickening compared with control plants [2].The most obvious factors to explain the reduced growth in plants exposed to salt are osmotic stress and $\mathrm{Na}^{+}$toxicity, including effects on mineral nutrition [3]. Expression some genes have been shown to increase in response to salinity, cold, drought and oxidative stress [4].

Gene expression is often different between organs and between stresses. For example DREB2A and DREB2B genes are highly expressed in roots in response to high salt and dehydration and in stems only in response to dehydration. Both had weak expression in leaves of Arabidopsis while RD29a was highly expressed in roots, stems and leaves after 5 hours dehydration. Also the expression of $D R E B 2 A$ and $D R E B 2 B$ was weak in flowers and siliques, and the expression of COR78/RD29a was also observed [5].

\section{MATERIALS AND METHODS}

Plants of Arabidopsis thaliana L.(Heyn) ecotype Columbia were grown in the control condition for about 5 to 6 weeks from sowing. The temperature used was $20^{\circ} \mathrm{C} / 15^{\circ} \mathrm{C}$ for day/night. Samples were collected for analysis at the same time when plants were transferred to other treatments (time 0 ). The samples were collected in $1.5 \mathrm{ml}$ micro centrifuge tubes, frozen in liquid nitrogen, and stored at $-80^{\circ} \mathrm{C}$ until neededFor salt treatment, compartments containing plants growing in soil were immersed in solution containing $250 \mathrm{mM} \mathrm{NaCl}$ for 15-20 minutes. For drought treatment, the leaves were collected in Petri dishes and the leaves were weighed immediately after cutting from the plants.

Epidermis or peeled leaves were used. Lower epidermis was peeled off using tweezers. Samples of peeled epidermis or whole leaf were collected and put it in micro tubes. About 15-25 mg was collected from epidermis and 100-150mg from leaves and used to analyze different periods of exposure to salt and drought stress. RNA extracted using TRI reagent and gene expression analysis by PCR

Copyright @ 2019: This is an open-access article distributed under the terms of the Creative Commons Attribution license which permits unrestricted use, distribution, and reproduction in any medium for non commercial use (NonCommercial, or CC-BY-NC) provided the original author and source are credited. 


\section{RESULTS AND DISCUSSION}

Shows gene expression for constitutively expressed reference genes Actin and EF1a and also for transcription factor COR and $L T P$ genes at $2 \mathrm{~h}$ and $6 \mathrm{~h}$ during drought and at $2 \mathrm{~h}, 6 \mathrm{~h}$ and $24 \mathrm{~h}$ under salt stress. The actin gene was expressed in both leaves and epidermis. The expression was lower in the epidermis at control, epidermis $2 \mathrm{~h}$ salt and epidermis $6 \mathrm{~h}$ salt. However, EF1a was expressed in most samples but it was undetectable in epidermis at $2 \mathrm{~h}$ drought and was weak in epidermis at $2 \mathrm{~h}$ of salt.

DREB2a was expressed in control leaves and leaves at $2 \mathrm{~h}$ and $6 \mathrm{~h}$ of drought and $2 \mathrm{~h}, 6 \mathrm{~h}$ and $24 \mathrm{~h}$ under salt stress (Fig 1). It was highly expressed in epidermis at $2 \mathrm{~h}$ under drought much more than in leaves under drought. It was undetectable at $2 \mathrm{~h}$ and $6 \mathrm{~h}$ salt in epidermis. On the other hand it was detectable at $24 \mathrm{~h}$ in epidermis under salt. CBF1 was expressed under drought stress in epidermis at $6 \mathrm{~h}$ and in leaves at $2 \mathrm{~h}$ compared with control levels. CBF1 had a higher expression in epidermis at $24 \mathrm{~h}$ in salt and in leaves at $24 \mathrm{~h}$ in salt compared with the control. CBF3 was detectable in all samples. It showed higher expression in the epidermis at $6 \mathrm{~h}$ and in leaves at $2 \mathrm{~h}$ than other samples in drought stress. It had a higher expression in leaves than epidermis under salt stress. COR78 was expressed when plants were exposed to drought in both leaves and epidermis at $2 \mathrm{~h}$ but expression decreased at $6 \mathrm{~h}$ in both leaves and epidermis (Fig 1). However, the expression was higher in leaves than epidermis under salt stress.

Most researchers have analysed acclimation in whole plants and organs but gene expression induced by cold is different in different tissues, for example epidermis and vascular transition zone in cereals [6]. In plants, about 60 to $77 \%$ of the genes do not have a strict tissue expression [7]. Many genes are coordinately regulated by salt and drought stress, supporting a high degree of cross talk between these types of stresses $[8,9]$.

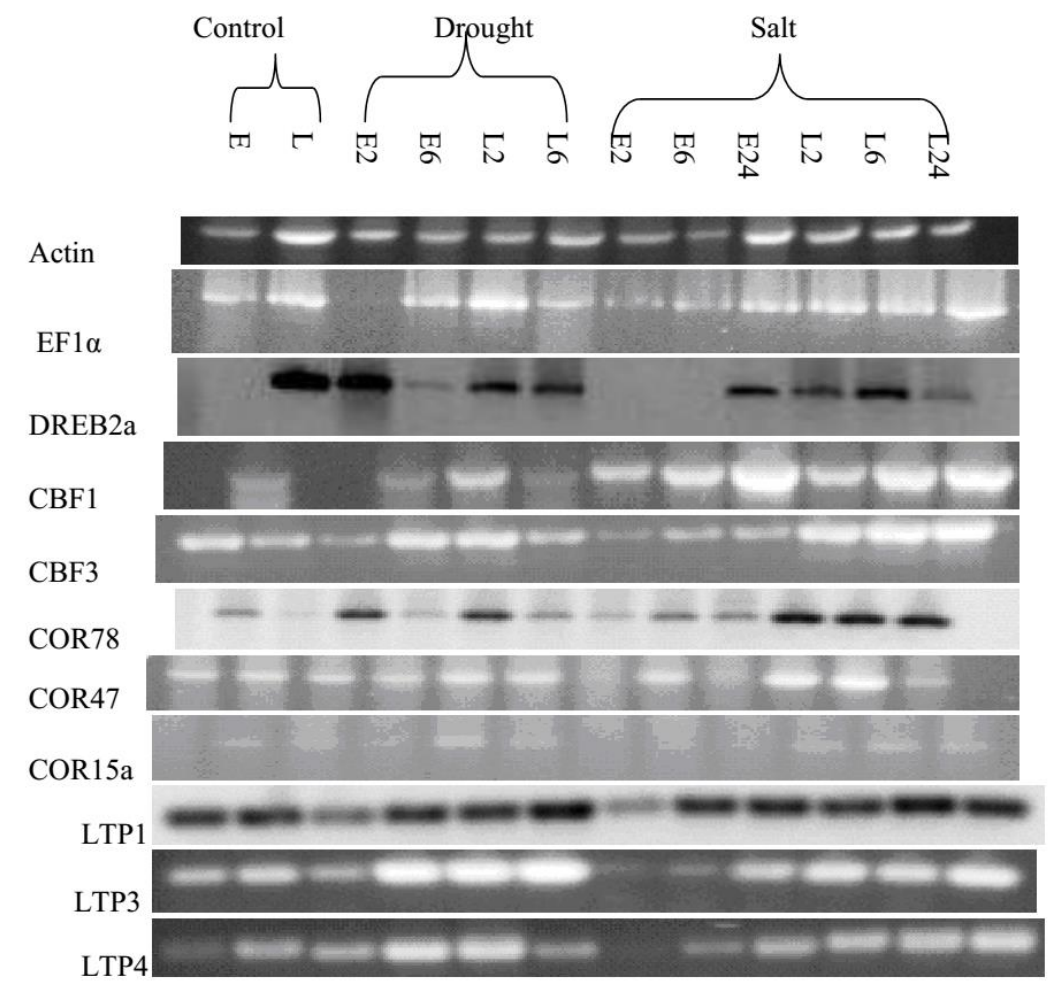

Fig-1: PCR products using cDNA from 100ng total RNA extracted from epidermis and leaves from Arabidopsis exposed to $2 \mathrm{~h}$ and $6 \mathrm{~h}$ drought or exposed to salt for $2 \mathrm{~h}, 6 \mathrm{~h}$ and $24 \mathrm{~h}$. E= epidermis, L= leaves.

\section{REFERENCES}

1. Serrano, R., Culiañz-Maciá, F. A., \& Moreno, V. (1998). Genetic engineering of salt and drought tolerance with yeast regulatory genes. Scientia Horticulturae, 78(1-4), 261-269.

2. Shabala, S., Shabala, L., \& Van Volkenburgh, E. (2003). Effect of calcium on root development and root ion fluxes in salinised barley seedlings. Functional plant biology, 30(5), 507-514.

3. Reid, R. J., \& Smith, F. A. (2000). The limits of sodium/calcium interactions in plant growth. Functional Plant Biology, 27(7), 709715.

4. Fang, Y., Liao, K., Du, H., Xu, Y., Song, H., Li, X., \& Xiong, L. (2015). A stress-responsive NAC transcription factor SNAC3 confers heat and drought tolerance through modulation of reactive oxygen species in rice. Journal of experimental botany, 66(21), 6803-6817.

5. Nakashima, K., Shinwari, Z. K., Sakuma, Y., Seki, M., Miura, S., Shinozaki, K., \& Yamaguchi-Shinozaki, K. (2000). Organization 
and expression of two Arabidopsis DREB2 genes encoding DRE-binding proteins involved in dehydration-and high-salinityresponsive gene expression. Plant molecular biology, 42(4), 657-665.

6. Bigley, G. A., \& Pearce, J. L. (1998). Straining for shared meaning in organization science: Problems of trust and distrust. Academy of management review, 23(3), 405-421.

7. Tadakuma, H., Okamura, H., Kitaoka, M., Iyama, K., \& Usuku, G. (1993). Association of immunolocalization of matrix metalloproteinase 1 with ovulation in hCG-treated rabbit ovary. Reproduction, 98(2), 503-508.

8. Rabbani, M. A., Maruyama, K., Abe, H., Khan, M. A., Katsura, K., Ito, Y., ... \& Yamaguchi-Shinozaki, K. (2003). Monitoring expression profiles of rice genes under cold, drought, and high-salinity stresses and abscisic acid application using cDNA microarray and RNA gel-blot analyses. Plant physiology, 133(4), 1755-1767.

9. Nakashima, K., Ito, Y., \& Yamaguchi-Shinozaki, K. (2009). Transcriptional regulatory networks in response to abiotic stresses in Arabidopsis and grasses. Plant physiology, 149(1), 88-95. 